\title{
Communication
}

\section{Is There Scope for a Novel Mycelium Category of Proteins alongside Animals and Plants?}

\author{
Emma J. Derbyshire $\mathbb{D}$ \\ Nutritional Insight, Surrey KT17 2AA, UK; emma@nutritional-insight.co.uk
}

Received: 3 August 2020; Accepted: 17 August 2020; Published: 21 August 2020

\begin{abstract}
In the 21st century, we face a troubling trilemma of expanding populations, planetary and public wellbeing. Given this, shifts from animal to plant food protein are gaining momentum and are an important part of reducing carbon emissions and consumptive water use. However, as this fast-pace of change sets in and begins to firmly embed itself within food-based dietary guidelines (FBDG) and food policies we must raise an important question-is now an opportunistic time to include other novel, nutritious and sustainable proteins within FBGD? The current paper describes how food proteins are typically categorised within FBDG and discusses how these could further evolve. Presently, food proteins tend to fall under the umbrella of being 'animal-derived' or 'plant-based' whilst other valuable proteins i.e., fungal-derived appear to be comparatively overlooked. A PubMed search of systematic reviews and meta-analytical studies published over the last 5 years shows an established body of evidence for animal-derived proteins (although some findings were less favourable), plant-based proteins and an expanding body of science for mycelium/fungal-derived proteins. Given this, along with elevated demands for alternative proteins there appears to be scope to introduce a 'third' protein category when compiling FBDG. This could fall under the potential heading of 'fungal' protein, with scope to include mycelium such as mycoprotein within this, for which the evidence-base is accruing.
\end{abstract}

Keywords: fungal protein; health; human research; mycelium; mycoprotein; protein classification; scientific awareness

\section{Introduction}

Population growth, climate change, food ethics and health are intricately intertwined-higher population growth entails more food production, more emissions and greater vulnerability to climate-related and health impacts [1]. Given this, viewpoints on what constitutes an 'ideal diet' are changing rapidly. The EAT-Lancet Food in the Anthropocene article published in January 2019 has been a powerful game changer-highlighting how food systems must urgently transform to feed growing populations in a manner that both supports environmental sustainability and human health [2].

Presently, there are sizeable discrepancies between protein guidance across global food-based dietary guidelines (FBDG). A review paper [3] evaluating FBDG across 90 countries demonstrated how interchangeable these are-countries display and describe what can generally be termed 'protein foods' in a wide variety of ways. Seventy-four percent of FBDG included a key message relating to protein foods, which included fish (58\% of countries), meat (53\%), legumes (41\%), eggs (31\%), poultry (29\%), dairy (9\%), nuts/seeds (8\%), and insects (only Kenya) [3]. Half of all countries with food key messages encompassing protein included animal and plant sources, whilst $11 \%$ did not have a protein foods key message at all [3]. Within the global FBDG analysis alternative sources of protein, such as fungal protein, were not mentioned.

Fungi were once considered to be plants due to them growing in soil and having rigid cell walls, but are now independently placed in their own kingdom as they are biologically distinct from 
plant-and animal-sourced foods [4]. The mycelium is the vegetative part of the fungi, but unlike yeast cells, which typically grow as a single cell, mycelium is filamentous and comprised of a mass of branching hyphae [5]. In nature, the mycelium plays a vital role within ecosystems by forming symbioses with trees and recycling carbon-it is interconnected within the soil with such complexity that some authors have coined the phrase 'wood wide web' [6]. Mycoprotein is one example of an important and well-established whole-food mycelium protein [7]. Derived from the filamentous fungus Fusarium venenatum, this was first discovered in the 1960s [8]. Since then, mycoprotein has been successfully produced by fermentation processes over the last three decades (please refer to Finnigan et al., 2011 for methods) [9]. Mycoprotein also has a benign environmental footprint, which has been demonstrated by lifecycle analysis [10].

Increasingly, consumers are becoming interested in meat analogs (imitators of meat), namely due to accelerating health and environmental awareness [11,12]. Subsequently, simulated meat products can provide high biological protein to consumers without placing heavy burdens on global natural resources [13]. Subsequently, meat analogs which do not involve raising livestock are predicted to expand within food markets, particularly in Asian countries where there are growing demands for these [11]. Mycelium proteins show great promise in achieving this, yet when compared with plant-based proteins they have been comparatively overlooked.

Given continuing changes to contemporary dietary patterns, the present paper evaluates how food proteins are presently categorised within FBDG and discusses whether there is potential to introduce other categories, including mycelium/fungal protein within these.

\section{Methods}

A PubMed was search was undertaken to obtain English-language, peer-reviewed systematic or meta-analytical papers published during the last 5 years. The search terms "animal-protein", "plant-protein" and "fungal-protein/mycelium/mycoprotein/mushrooms" and "health" were applied. Publications were excluded if they:

(1) Did not focus on human, adult populations;

(2) Were not a systematic review or meta-analysis publication;

(3) Focused on one specific global population/region;

(4) Did not clearly specify the protein of focus;

(5) Had research outcomes unrelated to health.

Some publications overlapped i.e., included both animal and plant-derived protein sources thus were placed under the category where significant findings were observed. A total of 15, 68 and 8 articles were identified for animal-derived, plant-derived and fungal-derived sectors, respectively. After screening for relevance 4, 9 and 4 publications were identified from each of the specified sectors. These findings are these are summarized in Table 1.

Table 1. Key systematic reviews and meta-analysis papers investigating animal, plant or fungal proteins and health.

\begin{tabular}{ccc}
\hline & Data Collation & Main Findings \\
\hline Guasch-Ferré et al. (2019) [14] & 36 studies & $\begin{array}{c}\text { Substituting red meat with high-quality plant protein sources (but not fish } \\
\text { or low-quality carbohydrates) resulted in favorable changes to blood } \\
\text { lipids and lipoproteins. }\end{array}$ \\
\hline Fan et al. (2019) [15] & 12 studies & $\begin{array}{c}\text { T2D risk } \uparrow \text { with } \uparrow \text { consumption of total protein and animal protein, red } \\
\text { meat, processed meat, milk, and eggs. Plant protein and yogurt had an } \\
\text { inverse relationship. }\end{array}$ \\
\hline Kim et al. (2017) [16] & 15 studies & $\begin{array}{c}\text { Inter-relations between meat intake and stroke risk differ by type of meat. } \\
\text { Red and processed meats replaced with white meat may be considered } \\
\text { for stroke prevention. }\end{array}$ \\
\hline
\end{tabular}


Table 1. Cont.

\begin{tabular}{|c|c|c|}
\hline & Data Collation & Main Findings \\
\hline Tian et al. (2017) [17] & 11 studies & $\begin{array}{l}\text { Red meat and processed meat are risk factors for T2D whilst soy and } \\
\text { dairy products appear protective. Egg and fish intake were not associated } \\
\text { with decreased T2D risk. }\end{array}$ \\
\hline \multicolumn{3}{|c|}{ Plant-Derived Proteins } \\
\hline Naghshi et al. (2020) [18] & 32 studies & $\begin{array}{l}\text { Intake of plant-protein was associated with a lower risk of all-cause and } \\
\text { cardiovascular disease mortality. }\end{array}$ \\
\hline Zhao et al. (2020) [19] & 32 studies & $\begin{array}{l}\text { Plant-protein could improve lipid profile in patients with } \\
\text { hypercholesterolemia. }\end{array}$ \\
\hline Blanco Mejia et al. (2019) [20] & 46 trials & $\begin{array}{l}\text { Soy protein significantly reduced LDL cholesterol by approximately } 3-4 \% \\
\text { in adults. }\end{array}$ \\
\hline Messina et al. (2018) [21] & 9 studies & $\begin{array}{l}\text { Soy protein supplementation produced similar gains in strength and LBM } \\
\text { in response to RET as whey protein. }\end{array}$ \\
\hline Shams-White et al. (2018) [22] & 7 trials & $\begin{array}{l}\text { Soy protein consumption versus animal protein was not more } \\
\text { advantageous at improving markers of bone health. }\end{array}$ \\
\hline Kou et al. (2017) [23] & 12 trials & $\begin{array}{c}\text { The ingestion of } \geq 25 \mathrm{~g} \text { soy protein per day had BP-lowering effects, } \\
\text { possibly due to isoflavones. }\end{array}$ \\
\hline Li et al. (2017) [24] & 112 trials & $\begin{array}{c}\text { Plant protein in substitution for animal protein } \downarrow \text { LDL cholesterol by } \\
0.16 \mathrm{mmol} / \mathrm{L} \text {, non-high-density lipoprotein cholesterol by } 0.18 \mathrm{mmol} / \mathrm{L} \\
\text { and apolipoprotein B by } 0.05 \mathrm{~g} / \mathrm{L} \text {. }\end{array}$ \\
\hline Eichelmann et al. (2016) [25] & 29 trials & $\begin{array}{l}\text { Plant-based diets were associated with improved markers of } \\
\text { inflammation, including CRP and IL-6. }\end{array}$ \\
\hline Viguiliouk et al. (2015) [26] & 13 trials & $\begin{array}{l}\text { Replacing animal with plant protein leas to modest improvements in } \\
\text { glycemic control in individuals with diabetes. }\end{array}$ \\
\hline \multicolumn{3}{|c|}{ Fungal-Derived Proteins } \\
\hline Cherta-Murillo et al. (2020) [27] & Five trials & $\begin{array}{l}\text { Results showed that mycoprotein reduced insulin levels. Acute } \\
\text { mycoprotein intake also decreased energy intake at an ad libitum meal and } \\
\text { post- } 24 \mathrm{~h} \text { in healthy lean, overweight and obese humans. }\end{array}$ \\
\hline Dicks and Ellinger (2020) [28] & Eight trials & $\begin{array}{l}\text { P. ostreatus intake may improve cardiometabolic health, but ongoing } \\
\text { research is needed. }\end{array}$ \\
\hline Cashman et al. (2016) [29] & Six trials & $\begin{array}{l}\text { Consumption of ultraviolet (UV)-exposed mushrooms may increase } \\
\text { serum 25(OH)D when baseline vitamin D status is low. }\end{array}$ \\
\hline Fritz et al. (2015) [30] & 28 studies & $\begin{array}{l}\text { Polysaccharide K may improve immune function, reduce } \\
\text { tumor-associated symptoms, and extend survival in lung cancer patients. }\end{array}$ \\
\hline
\end{tabular}

Key: BP, blood pressure; CRP, C-reactive protein; IL-6, interleukin-6; LBM, lean body mass; LDL, low-density

lipoprotein; RET, resistance exercise training; T2D, type 2 diabetes.

\section{Animal-Derived Proteins}

Meat production has been intensifying since the 1960s, but even more so from the 1980s to the present day, with some suggesting that the supply of meat products has risen by as much as $204 \%$ [31,32]. Over time there has been progressively more criticism over animal-derived proteins, particularly red and processed meats and the role that these have to play in the aetiology of chronic diseases and preterm mortality, although extended factors such as cooking methods also need to be better considered [33,34].

Animal-derived proteins are useful sources of bioavailable amino acids and micronutrients [35-37]. Different types of meat and fish, however, have been associated with different health outcomes [38]. For example, as shown in Table 1 meta-analytical data shows that substituting red and processed meats with white meat could reduce stroke risk [16]. Increasingly, red and processed meats have, however, been associated with elevated type 2 diabetes (T2D) risk, whilst egg and fish intakes do not appear to be as strongly related $[15,17]$.

In the United Kingdom, the Department for Environment, Food and Rural Affairs and Food Standards Agency define 'meat' and other similar specific terms like 'beef', 'lamb' and 'chicken' as mammal or bird skeletal muscle with natural tissue that is fit for human consumption [39].

The World Health Organisation has defined red meat as: "all mammalian muscle meat, including, beef, veal, pork, lamb, mutton, horse, and goat" [40]. Equally, processed meat has been defined as: "Meat that has been transformed through salting, curing, fermentation, smoking, or other processes to 
enhance flavour or improve preservation. Most processed meats contain pork or beef, but processed meats may also contain other red meats, poultry, offal, or meat by-products such as blood. Examples of processed meat include hot dogs (frankfurters), ham, sausages, corned beef, and biltong or beef jerky as well as canned meat and meat-based preparations and sauces" [40]. Even though these definitions have been clearly specified, the use and application of these vary extensively within epidemiological and observational research. For instance, a recent review pooling data from 369 articles evaluating 'muscle food consumption' highlighted that there were 1020 different dietary meat categories and 776 inter-changeable descriptions [41].

Another escalating concern of existing relevance is rising numbers of outbreaks of animal diseases, including avian influenza which are contributing to mounting distrust amongst consumers [42]. It has also been proposed that wild meat trade markets should be urgently disbanded given that these have been related to viral infections [31].

\section{Plant-Derived Proteins}

Definitions of 'plant-based' diets are being using widely within scientific and social domains. A basic internet search of 'definition of plant-based diets' yields around 82,900,000 results, many of which are somewhat nebulous. Earlier work discusses how plant-based foods have been common staples of traditional diets in Mediterranean and Asian regions, which typically include the consumption of large proportions of fruit, vegetables, legumes, whole grains, and nuts and smaller amounts of refined grains and red meat [43]. The EAT-Lancet Planetary Health Plate is also described as being predominantly 'plant-based' and broadly defines this as being comprised of approximately $50 \%$ or $500 \mathrm{~g}$ of fruit and vegetables daily [44].

Within the large US National Health and Nutrition Examination Survey (NHANES) an analysis of 'plant-based' foods defined these as having zero servings of dairy, meat, poultry, fish and eggs but providing servings of fruits, vegetables, legumes, grains, soy products and nuts/seeds [45]. The additional category of 'higher protein plant-based foods' was also used and comprised beans, peas, legumes, nuts, seeds and processed soy products [45]. Subsequently within the umbrella term 'plant proteins' there are many different food derivatives. For example, soybeans, chickpeas, soft wheat, alfalfa and spirulin are all examples of plant proteins, as are pulses such as peas, faba beans and lupins, although these tend to be used less, possibly due to less favourable sensory perceptions [46]. Quinoa and hempseed are other examples of plant proteins that are well regarded for their fibre, micronutrient and polyphenol profiles [47].

The terms 'vegetarian' and 'vegan' have had proposed legal definitions put forward by the German Federation for Food Law and Food Science, which have been looked on favourably by the German federal state [48]. Unfortunately, no such formalisation exists for the definition of 'plant-based'. Thus, quite often vegetarian, vegan, flexitarian and other deviations of different diets are being categorised as being plant-based. It is believed that the European Commission is also looking into the process of establishing legal definitions for vegetarian and vegan foods, but given the rapid state of changes towards plant-based diets, there is an urgent need to consider a formalised definition for this too [49].

As shown in Table 1, plant-based diets are increasingly being linked to health and well-being. For example, in the last five years alone five synthetic reviews have observed benefits for cardiovascular disease mortality, improved lipid profiles, markers of inflammation and glycaemic control, especially amongst participants with poor health i.e., hypercholesterolemia at baseline $[18,19,24-26]$. Of the plant-based proteins, the evidence for soy protein appears to be particularly strong, with potential benefits for blood pressure and low-density lipoprotein reduction $[20,23]$ and gains in strength and lean body mass [21].

\section{Mycelium/Fungal-Derived Proteins}

Fungi have been categorised as a separate and indeed 'Third Kingdom' due to their distinct cellular organisation, with these falling outside the dichotomy of animals and vegetables $[50,51]$. 
Previously Feeney and colleagues [4] have listed the major differences that separate fungi from animals and plants explaining that: (1) plants produce food through photosynthesis and have chlorophyll, (2) animals ingest their food and (3) fungi lack chlorophyll, exist on decaying material or can be grown using various substrates commercially. Fungi also contain chitin (a polysaccharide derivative of glucose) rather than cellulose, which is found in plants and ergosterol instead of cholesterol, which is found in animal and mammalian cells [4]. Their cell walls are a useful provider of beta glucan (1,3 and 1,6 linkage) [52].

Globally, fungal-derived proteins been gaining popularity. For example, global mushroom and truffle production has been reported to have grown from 500\% between 1980 and 2011 [53]. The main five mushroom producers in the world in 2011 were reported to be The Netherlands, Poland, Italy, China and the United States [54]. In terms of mushroom and truffle global production China has produced 65\% since 2009, the European Union (EU) 24\%, the United States 5\% and Canada, Indonesia and Japan about $1 \%$ each [54]. Mycoprotein is a widely accepted food product-sold as Quorn ${ }^{\mathrm{TM}}$. It is consumed internationally across 17 countries which includes the United States [55]. In the United Kingdom (UK) in 2019 Quorn $^{\mathrm{TM}}$ was positioned as the meat-free market leader and 39th largest UK brand with sales equivalent to $£ 188.3$ million and $£ 12.9$ million invested in New Product Development [56]. Quorn ${ }^{\mathrm{TM}}$ food shortages were observed early in 2020 in the UK due to a surge in popularity during Veganuary [56].

\subsection{Mushrooms}

It is well established that mushrooms are fungi-key planetary components that are often referred to as the "Forgotten Kingdom" $[4,57]$. These have been eaten over centuries with ancient Greeks claiming that mushrooms provided warriors in battle with strength, and similarly, Romans viewed them as the "Food of the Gods" [58]. Mushrooms are rarely discussed as a protein source for archaeological populations yet have relatively high nitrogen isotope values that could mimic meat-eating [59].

Nutritionally mushrooms typically comprise $50 \%$ to $65 \%$ total carbohydrate, $19 \%$ to $35 \%$ proteins (including lectins with proposed biological and medicinal activities), $2 \%$ to $6 \%$ fat (unsaturated fatty acids predominate over saturated fatty acids), are abundant in fat soluble vitamins and, along with their ergosterol content, are believed to be the only vegetarian source for vitamin D [60,61]. Alongside this, mushrooms also provide fibre polysaccharides and a range of bioactive molecules including $\beta$-glucans, triterpenoids and antioxidants which are gaining interest for their biological and medicinal properties [60]. The nutritional profile of different mushroom forms is summarised in Table 2, with dried mushrooms clearly concentrating nutritional values.

Table 2. Nutritional profile of fungal proteins.

\begin{tabular}{|c|c|c|c|c|}
\hline & Shitake, Dried, Raw & $\begin{array}{c}\text { Oyster } \\
\text { Mushrooms, Raw }\end{array}$ & $\begin{array}{c}\text { White } \\
\text { Mushrooms, Raw }\end{array}$ & $\begin{array}{l}\text { Mycoprotein per } 100 \mathrm{~g} \\
\text { (Wet Weight) * }\end{array}$ \\
\hline Energy, kcal & 296 & 8 & 7 & 85 \\
\hline Protein, $g$ & 9.6 & 1.6 & 1.0 & 11 \\
\hline Total fat, $g$ & 1.0 & 0.2 & 0.2 & 2.9 \\
\hline Saturated fatty acids, $g$ & 0.2 & $\operatorname{Tr}$ & 0.04 & 0.7 \\
\hline Monounsaturated fatty acids, $\mathrm{g}$ & 0.3 & $\operatorname{Tr}$ & $\operatorname{Tr}$ & 0.5 \\
\hline Polyunsaturated fatty acids, $g$ & 0.1 & 0.10 & 0.11 & 1.8 \\
\hline Total carbohydrate, $\mathrm{g}$ & 63.9 & $\operatorname{Tr}$ & 0.3 & 3.0 \\
\hline Sugars, $\mathrm{g}$ & $\mathrm{N}$ & $\operatorname{Tr}$ & 0.3 & 0.5 \\
\hline Dietary fiber, $g$ & $\mathrm{~N}$ & $\mathrm{~N}$ & 1.2 & 6.0 \\
\hline Riboflavin, mg & 1.27 & 0.4 & 0.27 & 0.26 \\
\hline Folate (B9), $\mu \mathrm{g}$ & $\mathrm{N}$ & $\mathrm{N}$ & 40 & 114 \\
\hline Vitamin B-12, $\mu \mathrm{g}$ & 0.0 & 0.0 & 0.0 & 0.71 \\
\hline
\end{tabular}


Table 2. Cont.

\begin{tabular}{ccccc}
\hline & Shitake, Dried, Raw & $\begin{array}{c}\text { Oyster } \\
\text { Mushrooms, Raw }\end{array}$ & $\begin{array}{c}\text { White } \\
\text { Mushrooms, Raw }\end{array}$ & $\begin{array}{c}\text { Mycoprotein per 100 g } \\
\text { (Wet Weight) }\end{array}$ \\
\hline Choline, mg & - & - & - & 180 \\
\hline Phosphorous, mg & 290 & 120 & 94 & 290 \\
\hline Zinc, mg & $\mathrm{N}$ & $\mathrm{Tr}$ & 0.6 & 0.21 \\
\hline Iron, mg & 1.7 & 1.9 & 0.05 & 4.6 \\
\hline Manganese, mg & $\mathrm{N}$ & 3.6 & 4 & 4.9 \\
\hline Sodium, mg & 13 & 77 & 5.0 \\
\hline
\end{tabular}

Sources: Finnigan et al. (2019) [55]; McCance and Widdowson's (2019) [62]. * Updated micronutrient data provided by Marlow foods.

From a health stance the Mushrooms and Health Summit Proceedings suggested some benefits for cognition, breast cancer risk reduction, weight management and oral health [54]. Meta-analytical work also shows that mushroom intake could be inversely associated with cancer risk, particularly breast cancer [63-65]. It has been also been proposed that mushroom consumption could protect against obesity-related hypertension and dyslipidaemia, possibly by mediating antioxidant and anti-inflammatory pathways [66,67]. As well as possessing antioxidative, anti-inflammatory and immunomodulating activities, it is also thought that mushroom polysaccharides could act as prebiotics in the digestive system [68].

More research is needed to study habitual intakes of mushrooms, and indeed, other fungal protein sources in relation to specific markers of health, as observational studies tend to overlook this important dietary constituent. One study, however, investigated the effects of eating $226 \mathrm{~g}$ of roasted Agaricus bisporus mushrooms finding that this significantly increased average stool weight and resulted in a greater abundance of Bacteroidetes (beneficial gut bacteria) and reduced levels of less favourable Firmicutes [69]. As shown in Table 1 a growing number of synthetic reviews have collated the health effects of mushroom and polysaccharide consumption, with some evidence for improved cardiometabolic health, vitamin D status and immune function [28-30]. Ongoing work is now needed to build on these provisional findings.

\subsection{Mycoprotein}

Mycoprotein, which is produced from Fusarium venenatum, is also a naturally occurring fungus [9]. Over 50 years ago Lord Rank of the Rank Hovis McDougall group sought to find a solution when there were similar problems to those of present day-population growth and food shortages $[8,55]$. His team of scientists collected and tested more than 3000 soil organisms until they discovered that Fusarium venenatum, a filamentous micro fungus that could fulfill such a need [55]. After a 10-year evaluation process, in 1983 the UK Ministry of Agriculture, Fisheries and Food approved mycoprotein for food use. Since then mycoprotein has been approved for sale in all EU counties, Switzerland and Norway, the USA, Canada, Australia and New Zealand and recently in Thailand [55]. In addition, a growing body of scientific evidence has looked at the metabolic, anabolic and broader health effects associated with mycoprotein consumption $[7,8,55]$.

In its food ingredient form, mycoprotein is relatively low in energy, total saturated and saturated fatty acids and a good provider of dietary fibre (Table 2). When compared and aligned against European Commission nutrition claims mycoprotein may be regarded as being: (1) 'high in protein' i.e., at least $20 \%$ of the energy value of the food is provided by protein, (2) 'low in fat' i.e., contains no more than $3 \mathrm{~g}$ of fat per $100 \mathrm{~g}$ of solids, (3) 'low in saturated fat' i.e., does not contain more than $1.5 \mathrm{~g}$ of saturated fatty acids per $100 \mathrm{~g}$ of solids and (4) 'high in fiber' i.e., contains at least $6 \mathrm{~g}$ of fiber per $100 \mathrm{~g}$ [70,71]. This fungal protein provides a wide spectrum of inorganic compounds and, when applying European Commission nutrient claims, mycoprotein falls under the category of being a source of riboflavin, folate, vitamin B12, phosphorous, zinc and manganese [70]. It contains $180 \mathrm{mg}$ choline per $100 \mathrm{~g}$ which has recently been highlighted as a nutrient of concern that could be lacking from diets in general, 
but particularly vegetarians and vegans who do not consume animal-derived foods-some of the main dietary providers of choline [72].

Mycoprotein is a good source of quality protein and abundant in essential amino acids (EAA) - providing all nine EAA (Table 3). As a percentage of total protein, its EAA composition is $41 \%$-similar to spirulina, making this higher than most other commonly consumed plant-based protein [55]. The Protein Digestibility Corrected Amino Acid Score (PDCAAS) ratio for mycoprotein has been shown to be 0.996 where measures of digestibility were characterised with human ileostomy patients [73]. The bioavailability of the protein in mycoprotein has been characterised where the effect of mycoprotein ingestion (a test drink providing a mass-matched $20 \mathrm{~g}, 40 \mathrm{~g}, 60 \mathrm{~g}$ or $80 \mathrm{~g}$ bolus of mycoprotein or $20 \mathrm{~g}$ milk protein) on EAA concentrations was studied in a single-blind, randomised, crossover study conducted on 12 healthy young males [74]. Mycoprotein ingestion led to slower and more sustained EAA and branched chain amino acid levels compared with milk, with evidence of a plateau at intakes of 60 to $80 \mathrm{~g}$ bolus of mycoprotein [74]. In addition, such high bioavailability has now been shown to stimulate muscle protein synthesis rates to a greater extent than milk protein in rested and exercised skeletal muscle of healthy young men [75].

Table 3. Essential amino acid profile of different protein sources (g amino acids per $100 \mathrm{~g}$ ).

\begin{tabular}{cccccc}
\hline & Animal-Based Protein & \multicolumn{2}{c}{ Plant-Based Protein } & \multirow{2}{*}{ Mycoprotein } \\
\cline { 1 - 4 } & Beef & Cows Milk & Soy Isolate * & Soy Concentrate * & \\
\hline Histidine & 0.30 & 0.09 & 0.6 & 0.4 & 0.39 \\
\hline Isoleucine & 0.87 & 0.20 & 1.1 & 0.8 & 0.57 \\
\hline Leucine & 2.53 & 0.32 & 1.8 & 1.3 & 0.95 \\
\hline Lysine & 1.60 & 0.26 & 1.4 & 0.2 & 0.91 \\
\hline Methionine & 0.50 & 0.08 & 0.3 & 0.9 & 0.23 \\
\hline Phenylalanine & 0.76 & 0.16 & 1.1 & 0.2 & 0.54 \\
\hline Tryptophan & 0.22 & 0.05 & 0.3 & 0.7 & 0.18 \\
\hline Threonine & 0.84 & 0.15 & 0.8 & 0.8 & 0.61 \\
\hline Valine & 0.94 & 0.22 & 1.1 & 0.60 \\
\hline
\end{tabular}

* Soy isolate and concentrate data have been adjusted to the same water content as mycoprotein. Source: Data provided by Marlow foods.

Interestingly, further research has suggested that it is the whole-food nature of the mycelium that is important in delivering this anabolic response [75]—a feature also demonstrated for whole egg where the consumption of whole eggs promotes greater stimulation of post-exercise muscle protein synthesis than the ingestion of isonitrogenous amounts of egg whites in young men [76]. Subsequently, both the bioavailability and the amino acid composition of mycoprotein position make it a promising dietary protein source-having potential to support skeletal muscle protein metabolism [7].

As well as work on protein quality and anabolism, the scientific evidence-base has been building allowing the impact of diets rich in fungal protein mycoprotein on metabolic markers of health to be characterised [8]. Several studies have observed either reductions in energy intakes or satiety effects associated with mycoprotein consumption [77-80]. A large body of evidence has documented favourable changes in blood lipid levels, including reduced plasma cholesterol, low-density lipoprotein and improved high-density lipoprotein [81-86]. Current work has shown that daily mycoprotein consumption over the course of one week modulates the plasma lipidome (the totality of lipids in cells), building on the theory that mycoprotein favourably modulates lipid regulation [87]. Other work has observed notable improvements in markers of glycaemia and insulinaemia, including reduced insulin levels and sustained hyperinsulinaemia and hyperaminoacidaemia $[74,77,88,89]$. As shown in Table 1 , results collated from five trials found that mycoprotein ingestion was associated with reduced insulin 
levels and appeared effective at reducing ad libitum energy intake in health lean, overweight and obese adults [27].

One school of thought is that these beneficial effects could be attributed to the profile (amount and type) of dietary fibre present in mycoprotein i.e., its chitin and beta-glucan profile [8,90]. Reduced energy intakes associated with fibre consumption could partly be due to the actions of short chain fatty acids (SCFAs) which are yielded from fibre by colonic bacteria [90]. Novel work shows that mycoprotein and extracted mycoprotein fibre are highly fermentable, resulting in a total SCFA production of 24.9 and $61.2 \mathrm{mmol} / \mathrm{L}$ respectively [90]. Another possibility is that the phytochemicals/pigments present in fungi could be inducing some of these effects. For example, an extraordinary range of colours are known to be produced by fungi including pigments such as azaphilones, flavins, melanins, phenazines, and quinines [91]. Continued research is needed.

\subsection{Others}

Single-cell proteins (SCPs) that can be produced by fungi are also gaining interest. SCPs grow rapidly and have a high protein content yet have minimal dependence of soil, water and climate conditions [92]. Some work has investigated the production of a vegan-based mycoprotein concentrate using a pea-industry by-product, again using edible filamentous fungi [93]. It was proposed that this protein source could help to provide protein and energy to the one billion people in the world failing to have access to this [93].

\section{Discussion and Future Directions}

Contemporary dietary patterns are changing-a shift being fueled by population growth, environmental awareness and health [94]. Subsequently, food systems, dietary viewpoints and guidelines are transforming. The 2019 EAT-Lancet Commission Food in the Anthropocene report [2] and its reflections on current food production systems has been at the epicentre of a wave of change, which is diffusing.

Already change can be seen in updated 2019 Australian Dietary Guidelines [95] which have embedded core elements from the planetary health diet-making vegetables and fruits half of the plate and providing advice to limit red meat and avoid processed meat, while opting for fish, chicken, beans, nuts and tofu as healthy and versatile protein sources. Whilst such changes are highly commendable in the bid to consume more 'plant-based' protein it could be questioned whether other valuable sustainable protein sources are being overlooked.

Fungi have distinct nutritional and bioactive profiles and the evidence-base with regard to health benefits has also been building. This is particularly evident with the mycelium mycoprotein, which has been successfully and sustainably produced since 1985 [55]. Mycoprotein is high in protein, provides the full range of essential amino acids, is low in fat, low in saturated fat, high in fibre and a source of riboflavin, folate, magnesium, phosphorous, copper, zinc, selenium and choline [96]. Alongside the recent systematic review showing that mycoprotein ingestion is associated with reduced insulin levels [27] at least 13 separate human studies have studied inter-relationships between mycoprotein consumption and human health [8], and more in recent years. Fungi are known to be rich sources of ergothioneine and glutathione, which are both potent antioxidants with potential anti-inflammatory properties [97]. The antiaging effects of bioactive molecules isolated from fungi are also beginning to be identified [98]. Similarly, the role of fungal metabolites in the gut 'mycobiome' and its relation to the onset of human diseases is also gaining attention [99].

Shifting protein intakes towards plant and fungal-derived proteins could also yield benefits from an environmental point of view. Table 4 provides a sustainability comparator and evaluates the carbon, land and water footprints of different food-based proteins. It can be seen that both plant-based protein and fungal protein have the lowest average carbon footprints $\left(1.02 \mathrm{~kg} \mathrm{CO}_{2} \mathrm{e} \mathrm{kg}^{-1}\right.$ and $0.8 \mathrm{CO}_{2} \mathrm{e} \mathrm{kg}^{-1}$, respectively). Beef has the highest land footprint of $0.0068 \mathrm{ha} \mathrm{kg}^{-1}$ ) and mycoprotein the lowest at just $0.00018 \mathrm{ha} \mathrm{kg}^{-1}$. Regarding water use-green, blue and grey water usage are highest for meat 
production and lowest for mycoprotein production. Figure 1 shows the global warming potential (GWP) of mycoprotein compared against different plant proteins showing that this is substantially lower than soybean protein isolate.

In terms of marketability, there is a growing demand for alternative and sustainable protein sources with a suitable nutritional profile and pleasant sensory attributes [100]. The public are becoming increasingly aware of the need for green yet cost-effective processing technologies [100] and the trend of flexitarianism has been gaining in popularity, particularly amongst females [101]. Given shifting consumer trends and health evidence, now appears to be the time to re-evaluate FBDG in the context of three distinct and separate food kingdoms-plant, animal and mycelium/fungal [4]. Given the large inconsistencies in protein guidance across global FBDG, fresh approaches need to be taken [3]. This includes placing an emphasis on consuming protein from various 'sectors' which could potentially be broadened into: animal-based protein, plant-based protein and mycelium/fungal-based protein.

Alongside this, the definition of 'plant-based' should be formally defined, as this is subject to misinterpretation. For example, extruded foods rich in plant protein are being developed to meet the needs of consumers [102]. It is unclear where such products would fit within food models. Fungi, by contrast, are a 'whole-food source' that are produced naturally in nature-just like fruits, vegetable- and animal-based protein and innately lends itself to the formation of a new food group.

Table 4. Sustainability comparator of different protein sources-summary of the average carbon, land and water footprints.

\begin{tabular}{|c|c|c|c|c|c|}
\hline & Carbon $\left(\mathrm{kg} \mathrm{CO}_{2} \mathrm{e} \mathrm{kg}^{-1}\right)$ & Land (ha kg-1) & Green Water $\left(\mathrm{L} \mathrm{kg}^{-1}\right)$ & Blue Water $\left(\mathrm{L} \mathrm{kg}^{-1}\right)$ & Grey Water $\left(\mathrm{L} \mathrm{kg}^{-1}\right)$ \\
\hline \multicolumn{6}{|c|}{ Animal-Based } \\
\hline Beef, general & 16.2 & 0.0068 & 13,921 & 752 & 1016 \\
\hline Beef, mixed & 26.7 & 0.0035 & 15,500 & 250 & 4000 \\
\hline Beef, grazed & 121 & 0.0049 & 16,500 & 300 & 5000 \\
\hline Pork & 8.29 & 0.0012 & 5070 & 416 & 509 \\
\hline \multicolumn{6}{|c|}{ Plant-Based } \\
\hline Soy & 1.02 & 0.0014 & 1855 & 240 & 573 \\
\hline \multicolumn{6}{|c|}{ Fungal } \\
\hline Mycoprotein & 0.8 & 0.00018 & 539 & 35 & 202 \\
\hline
\end{tabular}

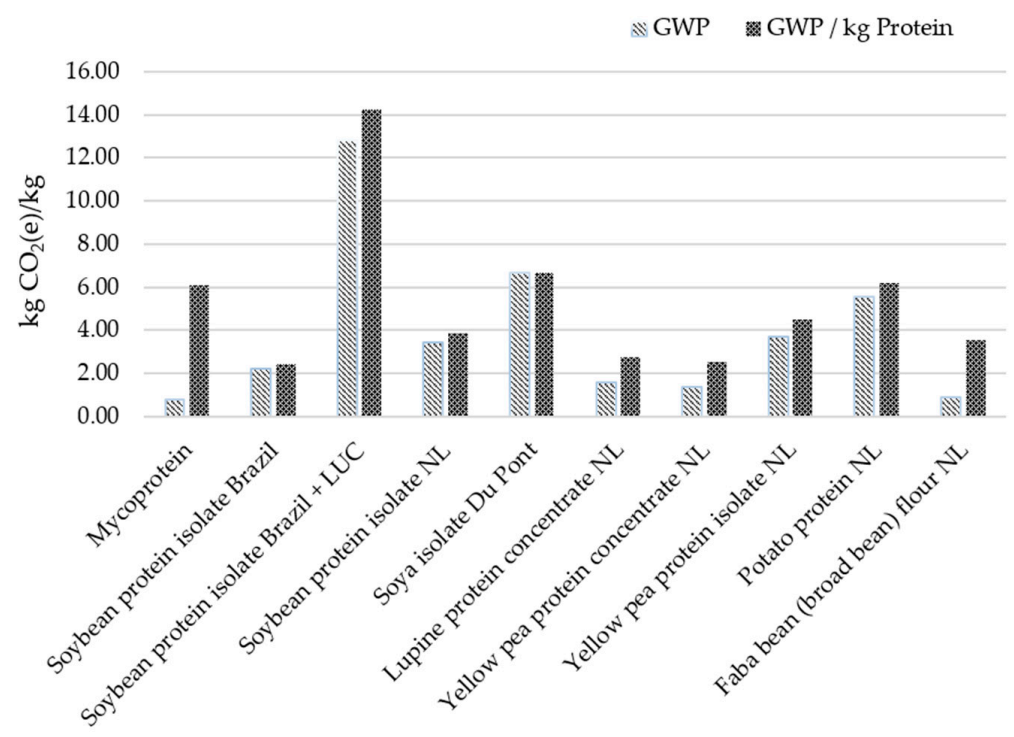

Figure 1. Comparison of mycoprotein global warming potential (GWP) with plant protein. Source: Finnigan et al. (2020) [105]. 
Taken together, future shifts in protein trends needn't result in byzantine definitions or group categories. Food policies and dietary guidelines should now be extended beyond going 'plant-based' and encompass protein consumption from different and newly specified food groups—one of which could potentially be fungal protein, or mycoprotein.

\section{Conclusions}

Food systems are undoubtedly changing-a change driven by complex interplay between population expansion, sustainability concerns and public health. This is having a domino effect on food policies and dietary guidelines, which are swiftly shifting. Whilst such changes are highly commendable, the current fashion to eat 'plant-based' diets could also be extended to other sustainable whole-food proteins. Bearing this in mind, it is now time for mycelium/fungal protein to come out of the shadows and position itself as a pivotal, third category of protein that sits comfortably beside plant-based and animal-based protein.

Funding: The author received funding provided by Marlow Foods Ltd., Stokesley United Kingdom. Marlow Foods played no role in developing or writing the publication. The content of the paper has been written independently.

Conflicts of Interest: The authors declare no conflict of interest.

\section{References}

1. Scovronick, N.; Budolfson, M.B.; Dennig, F.; Fleurbaey, M.; Siebert, A.; Socolow, R.H.; Spears, D.; Wagner, F. Impact of population growth and population ethics on climate change mitigation policy. Proc. Natl. Acad Sci. USA 2017, 114, 12338-12343. [CrossRef]

2. Willett, W.; Rockstrom, J.; Loken, B.; Springmann, M.; Lang, T.; Vermeulen, S.; Garnett, T.; Tilman, D.; DeClerck, F; Wood, A.; et al. Food in the Anthropocene: The EAT-Lancet Commission on healthy diets from sustainable food systems. Lancet 2019, 393, 447-492. [CrossRef]

3. Herforth, A.; Arimond, M.; Alvarez-Sanchez, C.; Coates, J.; Christianson, K.; Muehlhoff, E. A Global Review of Food-Based Dietary Guidelines. Adv. Nutr. 2019, 10, 590-605. [CrossRef]

4. Jo Feeney, M.; Miller, A.M.; Roupas, P. Mushrooms-Biologically Distinct and Nutritionally Unique: Exploring a "Third Food Kingdom". Nutr. Today 2014, 49, 301-307. [CrossRef]

5. Bayer, E. The Mycelium Revolution Is upon Us. 2019. Available online: https://blogs.scientificamerican.com/ observations/the-mycelium-revolution-is-upon-us/ (accessed on 18 August 2020).

6. Giovannetti, M.E.A. At the Root of the Wood Wide Web. Plant. Signal. Behav. 2006, 1, 1-5. [CrossRef]

7. Coelho, M.O.C.; Monteyne, A.; Dunlop, M.V.; Harris, H.C.; Morrison, D.J.; Stephens, F.B.; Wall, B.T. Mycoprotein as a possible alternative source of dietary protein to support muscle and metabolic health. Nutr. Res. Rev. 2019, 78, 486-497. [CrossRef]

8. Derbyshire, E.J.; Ayoob, K.T. Mycoprotein Nutritional and Health Properties. Nutr. Today Clin. Nutr. 2019, $54,1-9$.

9. Finnigan, T. Mycoprotein: Origins, production and properties. In Handbook of Food Proteins; Phillips, G.O., William, P.A., Eds.; Woodhead Publishing: London, UK, 2011; pp. 335-352.

10. The Carbon Trust. The Carbon Trust. Product Carbon Footprint and Reduction Certification Letter CERT-12751. Unpublished work. 2019.

11. Ismail, I.; Hwang, Y.H.; Joo, S.T. Meat analog as future food: A review. J. Anim. Sci. Technol. 2020, 62, 111-120. [CrossRef]

12. Malav, O.P.; Talukder, S.; Gokulakrishnan, P.; Chand, S. Meat analog: A review. Crit. Rev. Food Sci. Nutr. 2015, 55, 1241-1245. [CrossRef]

13. Kumar, P.; Chatli, M.K.; Mehta, N.; Singh, P.; Malav, O.P.; Verma, A.K. Meat analogues: Health promising sustainable meat substitutes. Crit. Rev. Food Sci. Nutr. 2017, 57, 923-932. [CrossRef]

14. Guasch-Ferre, M.; Satija, A.; Blondin, S.A.; Janiszewski, M.; Emlen, E.; O'Connor, L.E.; Campbell, W.W.; Hu, F.B.; Willett, W.C.; Stampfer, M.J. Meta-Analysis of Randomized Controlled Trials of Red Meat Consumption in Comparison With Various Comparison Diets on Cardiovascular Risk Factors. Circulation 2019, 139, 1828-1845. [CrossRef] [PubMed] 
15. Fan, M.; Li, Y.; Wang, C.; Mao, Z.; Zhou, W.; Zhang, L.; Yang, X.; Cui, S.; Li, L. Dietary Protein Consumption and the Risk of Type 2 Diabetes: ADose-Response Meta-Analysis of Prospective Studies. Nutrients 2019, 11, 2783. [CrossRef] [PubMed]

16. Kim, K.; Hyeon, J.; Lee, S.A.; Kwon, S.O.; Lee, H.; Keum, N.; Lee, J.K.; Park, S.M. Role of Total, Red, Processed, and White Meat Consumption in Stroke Incidence and Mortality: A Systematic Review and Meta-Analysis of Prospective Cohort Studies. J. Am. Heart Assoc. 2017, 6. [CrossRef]

17. Tian, S.; Xu, Q.; Jiang, R.; Han, T.; Sun, C.; Na, L. Dietary Protein Consumption and the Risk of Type 2 Diabetes: A Systematic Review and Meta-Analysis of Cohort Studies. Nutrients 2017, 9, 982. [CrossRef]

18. Naghshi, S.; Sadeghi, O.; Willett, W.C.; Esmaillzadeh, A. Dietary intake of total, animal, and plant proteins and risk of all cause, cardiovascular, and cancer mortality: Systematic review and dose-response meta-analysis of prospective cohort studies. BMJ 2020, 370, m2412. [CrossRef]

19. Zhao, H.; Song, A.; Zheng, C.; Wang, M.; Song, G. Effects of plant protein and animal protein on lipid profile, body weight and body mass index on patients with hypercholesterolemia: A systematic review and meta-analysis. Acta Diabetol. 2020. [CrossRef]

20. Blanco Mejia, S.; Messina, M.; Li, S.S.; Viguiliouk, E.; Chiavaroli, L.; Khan, T.A.; Srichaikul, K.; Mirrahimi, A.; Sievenpiper, J.L.; Kris-Etherton, P.; et al. A Meta-Analysis of 46 Studies Identified by the FDA Demonstrates that Soy Protein Decreases Circulating LDL and Total Cholesterol Concentrations in Adults. J. Nutr. 2019, 149, 968-981. [CrossRef]

21. Messina, M.; Lynch, H.; Dickinson, J.M.; Reed, K.E. No Difference between the Effects of Supplementing With Soy Protein Versus Animal Protein on Gains in Muscle Mass and Strength in Response to Resistance Exercise. Int. J. Sport Nutr. Exerc. Metab. 2018, 28, 674-685. [CrossRef]

22. Shams-White, M.M.; Chung, M.; Fu, Z.; Insogna, K.L.; Karlsen, M.C.; LeBoff, M.S.; Shapses, S.A.; Sackey, J.; Shi, J.; Wallace, T.C.; et al. Animal versus plant protein and adult bone health: A systematic review and meta-analysis from the National Osteoporosis Foundation. PLoS ONE 2018, 13, e0192459. [CrossRef]

23. Kou, T.; Wang, Q.; Cai, J.; Song, J.; Du, B.; Zhao, K.; Ma, Y.; Geng, B.; Zhang, Y.; Han, X.; et al. Effect of soybean protein on blood pressure in postmenopausal women: A meta-analysis of randomized controlled trials. Food Funct. 2017, 8, 2663-2671. [CrossRef]

24. Li, S.S.; Blanco Mejia, S.; Lytvyn, L.; Stewart, S.E.; Viguiliouk, E.; Ha, V.; de Souza, R.J.; Leiter, L.A.; Kendall, C.W.C.; Jenkins, D.J.A.; et al. Effect of Plant Protein on Blood Lipids: A Systematic Review and Meta-Analysis of Randomized Controlled Trials. J. Am. Heart Assoc. 2017, 6. [CrossRef] [PubMed]

25. Eichelmann, F.; Schwingshackl, L.; Fedirko, V.; Aleksandrova, K. Effect of plant-based diets on obesity-related inflammatory profiles: A systematic review and meta-analysis of intervention trials. Obes. Rev. 2016, 17, 1067-1079. [CrossRef] [PubMed]

26. Viguiliouk, E.; Stewart, S.E.; Jayalath, V.H.; Ng, A.P.; Mirrahimi, A.; de Souza, R.J.; Hanley, A.J.; Bazinet, R.P.; Blanco Mejia, S.; Leiter, L.A.; et al. Effect of Replacing Animal Protein with Plant Protein on Glycemic Control in Diabetes: A Systematic Review and Meta-Analysis of Randomized Controlled Trials. Nutrients 2015, 7, 9804-9824. [CrossRef]

27. Cherta-Murillo, A.; Lett, A.M.; Frampton, J.; Chambers, E.S.; Finnigan, T.J.A.; Frost, G.S. Effects of mycoprotein on glycaemic control and energy intake in humans: A systematic review. Br. J. Nutr. 2020, 123, 1321-1332. [CrossRef]

28. Dicks, L.; Ellinger, S. Effect of the Intake of Oyster Mushrooms (Pleurotus ostreatus) on Cardiometabolic Parameters-A Systematic Review of Clinical Trials. Nutrients 2020, 12, 1134. [CrossRef]

29. Cashman, K.D.; Kiely, M.; Seamans, K.M.; Urbain, P. Effect of Ultraviolet Light-Exposed Mushrooms on Vitamin D Status: Liquid Chromatography-Tandem Mass Spectrometry Reanalysis of Biobanked Sera from a Randomized Controlled Trial and a Systematic Review plus Meta-Analysis. J. Nutr. 2016, 146, 565-575. [CrossRef]

30. Fritz, H.; Kennedy, D.A.; Ishii, M.; Fergusson, D.; Fernandes, R.; Cooley, K.; Seely, D. Polysaccharide K and Coriolus versicolor extracts for lung cancer: A systematic review. Integr. Cancer Ther. 2015, 14, 201-211. [CrossRef]

31. González, N.; Marques, M.; Nadal José, M.; Domingo, L. Meat consumption: Which are the current global risks? A review of recent (2010-2020) evidences. Food Res. Int. 2020, 137, 109341. [CrossRef]

32. Basu, S. The transitional dynamics of caloric ecosystems: Changes in the food supply around the world. Crit. Public Health 2015, 25, 248-264. [CrossRef] 
33. Wolk, A. Potential health hazards of eating red meat. J. Intern. Med. 2017, 281, 106-122. [CrossRef]

34. Domingo, J.L.; Nadal, M. Carcinogenicity of consumption of red meat and processed meat: A review of scientific news since the IARC decision. Food Chem. Toxicol. 2017, 105, 256-261. [CrossRef] [PubMed]

35. Flachowsky, G.; Meyer, U.; Sudekum, K.H. Land Use for Edible Protein of Animal Origin-A Review. Animals 2017, 7, 25. [CrossRef] [PubMed]

36. Laskowski, W.; Gorska-Warsewicz, H.; Kulykovets, O. Meat, Meat Products and Seafood as Sources of Energy and Nutrients in the Average Polish Diet. Nutrients 2018, 10, 1412. [CrossRef] [PubMed]

37. Derbyshire, E. Associations between Red Meat Intakes and the Micronutrient Intake and Status of UK Females: A Secondary Analysis of the UK National Diet and Nutrition Survey. Nutrients 2017, 9, 768. [CrossRef]

38. Cuparencu, C.; Pratico, G.; Hemeryck, L.Y.; Sri Harsha, P.S.C.; Noerman, S.; Rombouts, C.; Xi, M.; Vanhaecke, L.; Hanhineva, K.; Brennan, L.; et al. Biomarkers of meat and seafood intake: An extensive literature review. Genes Nutr. 2019, 14, 35. [CrossRef]

39. DEFRA/FSA. Meat Products: Sell Them Legally in England. 2017. Available online: https://www.gov.uk/ guidance/meat-products-sell-them-legally-in-england (accessed on 18 August 2020).

40. WHO. Q\&A on the Carcinogenicity of the Consumption of Red Meat and Processed Meat. 2015. Available online: http:/www.cancer.ie/content/qa-carcinogenicityconsumption-red-meat-and-processedmeat\#sthash (accessed on 18 August 2020).

41. O'Connor, L.E.; Gifford, C.L.; Woerner, D.R.; Sharp, J.L.; Belk, K.E.; Campbell, W.W. Dietary Meat Categories and Descriptions in Chronic Disease Research Are Substantively Different within and between Experimental and Observational Studies: A Systematic Review and Landscape Analysis. Adv. Nutr. 2020, 11, 41-51. [CrossRef]

42. Wen, X.; Sun, S.; Li, L.; He, Q.; Tsai, F.S. Avian Influenza-Factors Affecting Consumers' Purchase Intentions toward Poultry Products. Int. J. Environ. Res. Public Health 2019, 16, 4139. [CrossRef]

43. Fung, T.T.; Hu, F.B. Plant-based diets: What should be on the plate? Am. J. Clin. Nutr. 2003, 78, 357-358. [CrossRef]

44. EAT. Healthy Diets for Sustainable Food Systems: Food Planet Health; EAT-Lancet Commission: Stockholm, Sweden, 2019.

45. Cifelli, C.J.; Houchins, J.A.; Demmer, E.; Fulgoni, V.L. Increasing Plant Based Foods or Dairy Foods Differentially Affects Nutrient Intakes: Dietary Scenarios Using NHANES 2007-2010. Nutrients 2016, 8, 422. [CrossRef]

46. Chardigny, J.; Walrand, S. Plant protein for food: Opportunities and bottlenecks. Oilseeds Fats Crops Lipids 2016, 1-6. [CrossRef]

47. Pihlanto, A.; Mattila, P.; Makinen, S.; Pajari, A.M. Bioactivities of alternative protein sources and their potential health benefits. Food Funct. 2017, 8, 3443-3458. [CrossRef] [PubMed]

48. Michail, N. Germany Backs Proposal for Legal Definition of Vegetarian and Vegan Food. 2016. Available online: https:/www.foodnavigator.com/Article/2016/06/01/Germany-backs-proposal-for-legaldefinition-of-vegetarian-and-vegan-food (accessed on 18 August 2020).

49. Michail, N. EU to Set Legal Definition of Vegetarian and Vegan Food. 2017. Available online: https://www. foodnavigator.com/Article/2017/11/03/EU-to-set-legal-definition-of-vegetarian-and-vegan-food (accessed on 18 August 2020).

50. Carlile, M.J.; Watkinson, S.J. The fungi as a major group of organisms. In The Fungi; Academic Press: London, UK, 2015.

51. Naranjo-Ortiz, M.A.; Gabaldon, T. Fungal evolution: Diversity, taxonomy and phylogeny of the Fungi. Biol. Rev. Camb. Philos Soc. 2019, 94, 2101-2137. [CrossRef] [PubMed]

52. Denny, A. Mycoprotein and health. Br. Nutr. Found. Nutr. Bull. 2008, 33, 298-310. [CrossRef]

53. FAOSTAT. Mushrooms and Truffles; Food and Agriculture Organization of the United Nations: Rome, Italy, 2013; Available online: http://data.un.org/Data.aspx?d=FAO\&f=itemCode:449 (accessed on 18 August 2020).

54. Feeney, M.J.; Dwyer, J.; Hasler-Lewis, C.M.; Milner, J.A.; Noakes, M.; Rowe, S.; Wach, M.; Beelman, R.B.; Caldwell, J.; Cantorna, M.T.; et al. Mushrooms and Health Summit proceedings. J. Nutr. 2014, 144, 1128S-1136S. [CrossRef]

55. Finnigan, T.J.A.; Wall, B.T.; Wilde, P.J.; Stephens, F.B.; Taylor, S.L.; Freedman, M.R. Mycoprotein: The Future of Nutritious Nonmeat Protein, a Symposium Review. Curr. Dev. Nutr. 2019, 3, nzz021. [CrossRef] 
56. Grocer. The Grocer. Britain's Biggest Brands 2020: The Top 100. 2020. Available online: https://www.thegrocer. co.uk/britains-biggest-brands/britains-biggest-brands-2020-the-top-100/603257.article (accessed on 18 August 2020).

57. De Mattos-Shipley, K.M.; Ford, K.L.; Alberti, F.; Banks, A.M.; Bailey, A.M.; Foster, G.D. The good, the bad and the tasty: The many roles of mushrooms. Stud. Mycol. 2016, 85, 125-157. [CrossRef]

58. Valverde, M.E.; Hernandez-Perez, T.; Paredes-Lopez, O. Edible mushrooms: Improving human health and promoting quality life. Int. J. Microbiol. 2015, 2015, 376387. [CrossRef]

59. Regana, H.; Lamb, A.; Wilkinson, D. The missing mushrooms: Searching for fungi in ancient human dietary analysis. J. Archaeol. Sci. 2016, 75, 139-143. [CrossRef]

60. Rathore, H.; Prasad, S.; Sharma, S. Mushroom nutraceuticals for improved nutrition and better human health: A review. PharmaNutrition 2017, 5, 35-46. [CrossRef]

61. Cardwell, G.; Bornman, J.F.; James, A.P.; Black, L.J. A Review of Mushrooms as a Potential Source of Dietary Vitamin D. Nutrients 2018, 10, 1498. [CrossRef]

62. PHE. Public Health England. McCance and Widdowson's Composition of Foods Integrated Dataset. 2019. Available online: https://www.gov.uk/government/publications/composition-of-foods-integrated-datasetcofid (accessed on 18 August 2020).

63. Shin, A.; Kim, J.; Lim, S.Y.; Kim, G.; Sung, M.K.; Lee, E.S.; Ro, J. Dietary mushroom intake and the risk of breast cancer based on hormone receptor status. Nutr. Cancer 2010, 62, 476-483. [CrossRef] [PubMed]

64. Li, J.; Zou, L.; Chen, W.; Zhu, B.; Shen, N.; Ke, J.; Lou, J.; Song, R.; Zhong, R.; Miao, X. Dietary mushroom intake may reduce the risk of breast cancer: Evidence from a meta-analysis of observational studies. PLoS ONE 2014, 9, e93437. [CrossRef] [PubMed]

65. Ba, D.; Ssentongo, P.; Beelman, R.B.; Gao, X.; Richie, J.P. Mushroom Consumption Is Associated with Low Risk of Cancer: A Systematic Review and Meta-Analysis of Observation Studies. Curr. Dev. Nutr. 2020, 4, 307. [CrossRef]

66. Ganesan, K.; Xu, B. Anti-Obesity Effects of Medicinal and Edible Mushrooms. Molecules 2018, $23,2880$. [CrossRef] [PubMed]

67. Grotto, D.; Camargo, I.F.; Kodaira, K.; Mazzei, L.G.; Castro, J.; Vieira, R.A.L.; Bergamaschi, C.C.; Lopes, L.C. Effect of mushrooms on obesity in animal models: Study protocol for a systematic review and meta-analysis. Syst. Rev. 2019, 8, 288. [CrossRef]

68. Friedman, M. Mushroom Polysaccharides: Chemistry and Antiobesity, Antidiabetes, Anticancer, and Antibiotic Properties in Cells, Rodents, and Humans. Foods 2016, 5, 80. [CrossRef]

69. Hess, J.; Wang, Q.; Gould, T.; Slavin, J. Impact of Agaricus bisporus Mushroom Consumption on Gut Health Markers in Healthy Adults. Nutrients 2018, 10, 1402. [CrossRef]

70. EC. Efsa, regulation (ec) no 1924/2006 of the european parliament and of the council of 20 December 2006 on nutrition and health claims made on foods. Off. J. Eur. Union 2006, 1994, 2006.

71. European Comminsion. Commission Directive 2008/100/EC of 28 October 2008 amending Council Directive 90/496/EEC on nutrition labelling for foodstuffs as regards recommended daily allowances, energy conversion factors and definitions. Off. J. Eur. Union 2008, 285, 9.

72. Derbyshire, E. Could we be Overlooking a Potential Choline Crisis in the United Kingdom. BMJ Nutr. Prev. Health 2019, 1-4. [CrossRef]

73. Edwards, D.G.; Cummings, J.H. The protein quality of mycoprotein. Proc. Nutr. Soc. 2010, 69. [CrossRef]

74. Dunlop, M.V.; Kilroe, S.P.; Bowtell, J.L.; Finnigan, T.J.A.; Salmon, D.L.; Wall, B.T. Mycoprotein represents a bioavailable and insulinotropic non-animal-derived dietary protein source: A dose-response study. Br. J. Nutr. 2017, 118, 673-685. [CrossRef] [PubMed]

75. Monteyne, A.J.; Coelho, M.O.; Porter, C.; Abdelrahman, D.R.; Jameson, T.S.; Jackman, S.R.; Blackwell, J.R.; Finnigan, T.J.; Stephens, F.B.; Dirks, M.L.; et al. Mycoprotein ingestion stimulates protein synthesis rates to a greater extent than milk protein in rested and exercised skeletal muscle of healthy young men. Am. J. Clin. Nutr. 2020, 112, 318-333. [CrossRef]

76. van Vliet, S.; Shy, E.L.; Abou Sawan, S.; Beals, J.W.; West, D.W.; Skinner, S.K.; Ulanov, A.V.; Li, Z.; Paluska, S.A.; Parsons, C.M.; et al. Consumption of whole eggs promotes greater stimulation of postexercise muscle protein synthesis than consumption of isonitrogenous amounts of egg whites in young men. Am. J. Clin. Nutr. 2017, 106, 1401-1412. [CrossRef] 
77. Bottin, J.H.; Swann, J.R.; Cropp, E.; Chambers, E.S.; Ford, H.E.; Ghatei, M.A.; Frost, G.S. Mycoprotein reduces energy intake and postprandial insulin release without altering glucagon-like peptide-1 and peptide tyrosine-tyrosine concentrations in healthy overweight and obese adults: A randomised-controlled trial. Br. J. Nutr. 2016, 116, 360-374. [CrossRef] [PubMed]

78. Turnbull, W.H.; Walton, J.; Leeds, A.R. Acute effects of mycoprotein on subsequent energy intake and appetite variables. Am. J. Clin. Nutr. 1993, 58, 507-512. [CrossRef]

79. Williamson, D.A.; Geiselman, P.J.; Lovejoy, J.; Greenway, F.; Volaufova, J.; Martin, C.K.; Arnett, C.; Ortego, L. Effects of consuming mycoprotein, tofu or chicken upon subsequent eating behaviour, hunger and safety. Appetite 2006, 46, 41-48. [CrossRef]

80. Burley, V.; Paul, A.; Blundell, J.E. Influence of a high-fibre food (myco-protein) on appetite: Effects on satiation (within meals) and satiety (following meals). Eur. J. Clin. Nutr. 1993, 47, 409-418.

81. Ruxton, C.; McMilan, B. The impact of mycoprotein on blood cholesterol levels: A pilot study. Br. Food J. 2010, 112, 109. [CrossRef]

82. Turnbull, W.H.; Leeds, A.R.; Edwards, G.D. Effect of mycoprotein on blood lipids. Am. J. Clin. Nutr. 1990, 52, 646-650. [CrossRef]

83. Turnbull, W.H.; Leeds, A.R.; Edwards, D.G. Mycoprotein reduces blood lipids in free-living subjects. Am. J. Clin. Nutr. 1992, 55, 415-419. [CrossRef] [PubMed]

84. Ishikawa, T. Effect of mycoprotein on serum lipids and apolipoproteins in normolipidemic and hypercholesterolemic subjects. Atherosclerosis 1994, 109, 76. [CrossRef]

85. Nakamura, H.; Ishikawa, T.; Akanuma, M.; Nishiwaki, M.; Yamashita, T.; Tomiyasu, K.; Yoshida, H.; Nishio, E.; Hosoai, K.; Shiga, H.; et al. Effect of mycoprotein intake on serum lipids of healthy subjects. Prog. Med. 1994, 14, 1972-1976.

86. Homma, Y.; Nakamura, H.; Kumagai, Y.; Ryuzo, A.; Saito, Y.; Ishikawa, T.; Takada, K.; Yamagami, H.; Kikuchi, H.; Inadera, H. Effects of eight week ingestion of mycoprotein on plasma levels of lipids and Apo (Lipo) proteins. Prog. Med. 1995, 15, 183-195.

87. Coelho, M.O.C. Daily mycoprotein consumption for one week does not affect insulin sensitivity or glycaemic control but strongly modulates the plasma lipoma. Br. J. Nutr. 2020, submitted.

88. Bottin, J.H.; Cropp, E.; Finnigan, T.J.A.; Hogban, A. Mycoprotein reduces energy intake and improves insulin sensitivity compared to chicken. Obes. Facts 2012, 5, 55-79.

89. Turnbull, W.H.; Ward, T. Mycoprotein reduces glycemia and insulinemia when taken with an oral-glucose-tolerance test. Am. J. Clin. Nutr. 1995, 61, 135-140. [CrossRef]

90. Harris, H.C.; Edwards, C.A.; Morrison, D.J. Short Chain Fatty Acid Production from Mycoprotein and Mycoprotein Fibre in an In Vitro Fermentation Model. Nutrients 2019, 11, 800. [CrossRef]

91. Kalra, R.; Conlan, X.A.; Goel, M. Fungi as a Potential Source of Pigments: Harnessing Filamentous Fungi. Front. Chem. 2020, 8, 369. [CrossRef]

92. Nangul, A.; Bhatia, R. Microorganisms: A marvellous source of single cell proteins. J. Microbiol. Biotechnol. Food Sci. 2013, 3, 15-18.

93. Souza Filho, P.F.; Nair, R.B.; Andersson, D.; Lennartsson, P.R.; Taherzadeh, M.J. Vegan-mycoprotein concentrate from pea-processing industry byproduct using edible filamentous fungi. Fungal. Biol. Biotechnol. 2018, 5, 5. [CrossRef] [PubMed]

94. Cena, H.; Calder, P.C. Defining a Healthy Diet: Evidence for the Role of Contemporary Dietary Patterns in Health and Disease. Nutrients 2020, 12, 334. [CrossRef] [PubMed]

95. AGDoH. The Australian Dietary Guidelines; Australian Government, Department of Health: Canberra, Australia, 2019.

96. Derbyshire, E. Protein Guidance-Is It Time for an Update? Dietetics Today 2020, 22-23.

97. Kalaras, M.D.; Richie, J.P.; Calcagnotto, A.; Beelman, R.B. Mushrooms: A rich source of the antioxidants ergothioneine and glutathione. Food Chem. 2017, 233, 429-433. [CrossRef] [PubMed]

98. Martel, J.; Ojcius, D.M.; Ko, Y.F.; Chang, C.J.; Young, J.D. Antiaging effects of bioactive molecules isolated from plants and fungi. Med. Res. Rev. 2019, 39, 1515-1552. [CrossRef] [PubMed]

99. Chin, V.K.; Yong, V.C.; Chong, P.P.; Amin Nordin, S.; Basir, R.; Abdullah, M. Mycobiome in the Gut: A Multiperspective Review. Mediat. Inflamm. 2020, 2020, 9560684. [CrossRef] 
100. Fasolin, L.H.; Pereira, R.N.; Pinheiro, A.C.; Martins, J.T.; Andrade, C.C.P.; Ramos, O.L.; Vicente, A.A. Emergent food proteins-Towards sustainability, health and innovation. Food Res. Int. 2019, 125, 108586. [CrossRef]

101. Derbyshire, E.J. Flexitarian Diets and Health: A Review of the Evidence-Based Literature. Front. Nutr. 2016, 3, 55. [CrossRef]

102. Saint-Eve, A.; Granda, P.; Legay, G.; Cuvelier, G.; Delarue, J. Consumer acceptance and sensory drivers of liking for high plant protein snacks. J. Sci. Food Agric. 2019, 99, 3983-3991. [CrossRef]

103. The Carbon Trust. Quorn Footprint Comparison Report. 2018. Available online: https://www.quorn.co.uk/ files/content/Carbon-Trust-Comparison\%20Report-2018.pdf (accessed on 18 August 2020).

104. CT. The Carbon Trust. Quorn-Product Carbon Footprinting and Labeling. 2019. Available online: https://www.carbontrust.com/our-clients/q/quorn-product-carbon-footprinting-and-labeling/ (accessed on 18 August 2020).

105. Finnigan, T.; Abbott, C.; Thornton, H.; Needham, L. Mycoprotein Comparative Land Use and GWP Q\&A. Unpublished work. 2020.

(C) 2020 by the author. Licensee MDPI, Basel, Switzerland. This article is an open access article distributed under the terms and conditions of the Creative Commons Attribution (CC BY) license (http://creativecommons.org/licenses/by/4.0/). 